gift, and a scaraboid of his queen Tiy (Pl. XXXII B. 2) was found on the floor of 'Structure II'. For, even in its short period, the 'Fosse Temple' was twice rebuilt, and on each occasion considerably enlarged.

Nothing datable was found earlier than Thothmes III (1501-1447 B.c.) or later than Rameses II (1292-1225 B.c.), and there is ample evidence that the temple was burnt in the period of invasion and disorder in the years after 1200 B.c. The strew of vessels, bones from sacrificial animals, and other objects on the floor aud benches of 'Structure III' suggests to the excavators (p. 27) that a ceremony was in progress when the building caught fire and collapsed. But no members of that congregation perished there.

Though doubtless other parts of the site will reveal more, the contents of the 'Fosse Temple' give a vivid glimpse of the material culture of its votaries, which in many respects was high. Special attention may be called to the toiletvessels of variegated glass, the shapely stone jugs and bowls, the beads and rich pectoral collars in glazed paste, the engraved cylinder-seals of various Syrian styles, and the wide range of pottery types, which, as usual, offer suggestive synchronisms with other Palestinian sites.

Public attention was early attracted to the two painted inscriptions on vases, in a rough approximation to the script eventually standardized in Phœnicia. Here there is a careful summary of the divergent views of experts, and some constructive criticism (Ch. iv): an amusing 'warning to epigraphists' (p. 93) is supplied by a peasant's letter to one of the excavators, actually in English and in our alphabet, but uncomfortably like the writing on the 'Duweir Ewer'. Was the spelling of the Duweir scribe as good as his script?

Few recent memoirs in archæology have been so carefully edited and published so handsomely-or so cheaply. The photography is admirable, and the coloured plates exceptionally pleasing. Besides group-registers and inventories of the finds, there is a very useful list of the biblical passages which the 'Fosse Temple' and its equipment illustrate JoHn L. MYres.

\title{
YEAST PRODUCTION
}

\section{The Manufacture of Compressed Yeast}

By F. G. Walter. Pp. viii $+254+3$ plates. (London : Chapman and Hall, Ltd., 1940.) 15s. net.

$\mathrm{A}^{\mathrm{T}}$ LTHOUGH leavening agents have been known since the days of ancient Rome, it remained for Louis Pasteur to analyse their nature and to demonstrate the practical potentialities of the common yeasts. Now, in the course of a few years, as Mr. F. G. Walter tells us, the manufacture of compressed yeast has evolved from obscurity to an industry of not inconsiderable importance. The work under review has been written from the strictly technical point of view and provides an unusually readable account of the carefully controlled processes which go to the successful large-scale production of this commodity. The author's treatment is comprehensive, and affords a full explanation of the guiding principles involved at each stage of the process.

To the general biological reader the book should also prove of considerable interest in that it shows how carefully ascertained facts as to the optimum conditions for the growth of the yeast organism have been applied on a commercial scale so that maximum yields may be obtained. This, indeed, is a fascinating aspect of the subject, and one which has been handled with commendable clarity.
The opening chapter deals, in sufficient detail for technical purposes, with the several species of Saccharomyces and with the undesirable pseudoyeasts, moulds and bacteria which may vitiate pure cultures. The author then passes on to the isolation of yeasts in pure culture, the production of seed yeast, the preparation of wort, the differential fermentation of a grain brew (that is, nonalcoholic fermentation of this material so as to provide the growing yeast with a uniform concentration of nourishment), yeast production from molasses and from spirit fermentations. In each instance, full instructions are given as to the method of handling the raw materials, the timing of the process during its several phases, and the precise nature of the supervision that must be maintained.

The two concluding chapters are devoted to the preparation of dried yeast and yeast foods and to the organization and equipment of the yeast factory. In the latter, not the least important unit is the laboratory. To its equipment and to the methods of analyses to be followed the author has made appropriate references. In conclusion, the book is one which can be recommended to the general biological reader for its interest and to the technician engaged in compressed yeast production for its utility. 